\title{
The impact of malaria in pregnancy on infant susceptibility to malaria infection
}

\author{
Ratni Indrawanti ${ }^{1 *}$, Mahardika Wijayanti ${ }^{2}$, Mochamad Hakimi $^{3}$, Mohammad Juffrie, ${ }^{1}$ \\ Enny Kenangalem ${ }^{4}$, Faustina Helena Burdam ${ }^{4}$, Leily Triyanti ${ }^{5}$, Rintis Noviyanti ${ }^{5}$, Din \\ Syafruddin $^{5}$, Rukhsana Ahmed ${ }^{6}$, Feiko ter Kuile ${ }^{6}$, Jeanne Rini Poespoprojo ${ }^{7}$ \\ ${ }^{1}$ Department of Pediatrics, Faculty of Medicine, Public Health and Nursing/Dr. Sardjito General \\ Hospital, ${ }^{2}$ Department of Parasitology, Faculty of Medicine, Public Health and Nursing, ${ }^{3}$ Department \\ of Obstetric and Genecology, Faculty of Medicine, Publlic Health and Nursing/Dr. Sardjito General \\ Hospital, Universitas Gadjah Mada, Yogyakarta, ${ }^{4}$ Papua Community and Health Development \\ Foundation, Jayapura, ${ }^{5}$ Eijkman Institute for Molecular Biology, Jakarta, ${ }^{6}$ Liverpool School of \\ Tropical Medicine, UK, ${ }^{7}$ Mimika District Hospital, Timika, Papua
}

DOI: http://dx.doi.org/10.19106/JMedSci005002201807

\section{ABSTRACT}

Malaria infection during pregnancy is a significant global health problem with substantial risks for pregnant women, her foetus, and the newborn child. Infant malaria is a major public health concern in Timika, Papua. The aim of the study was to investigate the impact of malaria during pregnancy on infant's susceptibility to malaria infections, the timing of its occurrence, the number of malaria infections during pregnancy. This was a cohort prospective study conducted in Timika, Papua from October 2013 to September 2016. Malaria investigation was done by microscopic and PCR methods. Demographic data and malaria status of mother-infant pairs were collected and analyzed by SPSS 22.0 version. One hundred seventy-eight infants consisting of 95 (53.37\%) infants born to mothers with malaria and $83(46.63 \%)$ without malaria 91 (51.12\%) boys and $87(48.88 \%)$ girls were involved in the study. The mean of mothers' ages were $25.35 \pm 6.30$ vs. $26.0 \pm$ 5.69 years. At the ages of 6 and 12 months, infants born to malaria positive mothers were more susceptible to malaria infections compared to infants born to malaria negative mothers with $\mathrm{RR}=3.49 ; 95 \% \mathrm{Cl}: 1.02-11.96 ; \mathrm{p}=0.03$ and $\mathrm{RR}=8.74 ; 95 \% \mathrm{Cl}: 1.14-$ $66.81 ; \mathrm{p}=0.01$, respectively. Independent risk factors of infant susceptibility to malaria infection during the first year of life were malaria in pregnancy (MiP) in $2^{\text {nd }}$ trimester (RR $=4.50 ; 95 \% \mathrm{Cl}: 1.5-13.49 ; \mathrm{p}=0.07)$, pregnant women who only got malaria infection 1 time during pregnancy $(\mathrm{RR}=2.95 ; 95 \% \mathrm{Cl}: 1.04-8.33 ; \mathrm{p}=0.04)$, and Papuan ethnicity $(\mathrm{RR}=3.58 ; 95 \% \mathrm{Cl}: 1.22-10.59 ; \mathrm{p}=0.02)$. In conclusion, infant susceptibility to malaria is associated with maternal malaria status during pregnancy. MiP in second trimester, pregnant women who only had malaria once and Papuan ethnicity were independent risk factors for infant's increased susceptibility to malaria infection.

\section{ABSTRAK}

Infeksi malaria selama kehamilan merupakan masalah kesehatan global yang signifikan dengan risiko besar bagi ibu hamil, janin, dan bayi yang dilahirkan. Malaria pada bayi merupakan masalah kesehatan masyarakat utama di Timika, Papua. Penelitian ini bertujuan untuk mengkaji dampak malaria selama kehamilan terhadap kerentanan bayi pada infeksi malaria, waktu terjadinya infeksi malaria pada ibu, jumlah infeksi malaria selama kehamilan. Penelitian ini merupakan penelitian kohort prospektif yang dilakukan di Timika, Papua dari bulan Oktober 2013 sampai September 2016. Pemeriksaan malaria pada wanita hamil dan bayi dilakukan dengan metode mikroskopik dan PCR. Data demografi dan status

\footnotetext{
* corresponding author: ratni_iw@yahoo.com
} 
malaria pasangan ibu-bayi dikumpulkan dan dianalisis dengan SPSS versi 22.0. Sebanyak 178 bayi yang terdiri dari $95(53,37 \%)$ bayi yang lahir dari ibu dengan malaria dan 83 $(46,63 \%)$ tanpa malaria dan $91(51,12 \%)$ bayi laki-laki dan $87(48,88 \%)$ bayi perempuan dilibatkan dalam penelitian. Rata-rata usia ibu adalah $25,35 \pm 6,30$ vs $26,0 \pm 5,69$ tahun. Pada usia 6 dan 12 bulan, bayi yang lahir dari ibu positif malaria lebih rentan terhadap infeksi malaria dibandingkan dengan bayi dari ibu negatif malaria $(R R=3,49$; IK $95 \%$ : $1,02-11,96 ; p=0,03$ dan $R R=8,74 ; \mathrm{IK} 95 \%: 1,14-66,81 ; \mathrm{p}=0,01)$. Faktor risiko independen pada kerentanan bayi terhadap infeksi malaria selama tahun pertama adalah malaria pada kehamilan saat trimester kedua $(\mathrm{RR}=4,50 ; \mathrm{IK} 95 \%: 1,5-13,49 ; \mathrm{p}=$ 0,07 ), wanita hamil yang hanya terinfeksi malaria 1 kali selama kehamilan (RR $=2,95$; IK 95\%: 1,04-8,33; $\mathrm{p}=0,04)$, dan etnis Papua (RR = 3,58; IK 95\%: 1,22-10,59; $\mathrm{p}=$ 0,02 ). Dapat disimpulkan, kerentanan bayi terhadap malaria berhubungan dengan status malaria ibu selama kehamilan. Malaria pada kehamilan trimester kedua, wanita hamil yang hanya terinfeksi malaria satu kali selama kehamilan dan etnis Papua adalah faktor risiko independen terkait peningkatan kerentanan bayi terhadap infeksi malaria.

Keywords: Malaria - pregnancy - infant susceptibility - Timika Papua - risk factors -

\section{INTRODUCTION}

Malaria is a mosquito-borne infectious disease caused by the parasite Plasmodium. The predominant species are Plasmodium falciparum and $P$. vivax with an estimated 182.2 million clinical cases of $P$. falciparum malaria, 15.8 million clinical cases of $P$. vivax malaria and 584,000 deaths attributable to malaria every year. ${ }^{1}$ The greatest burden of disease is reported in young children and pregnant women. ${ }^{2}$ Annually, 88.2 (70\%) of 125.2 million pregnancies in malaria endemic regions occur in the Asia-Pacific area. ${ }^{3}$

Malaria in pregnancy (MiP) or pregancyassociated malaria, is defined as peripheral or placental infection by Plasmodium. The MiP presents as a major public health concern due to significant adverse health effects on both the mother and the fetus. ${ }^{4}$ The effects of $\mathrm{MiP}$ on infants include intra-uterine growth retardation (IUGR) and pre-term delivery, low birth weight (LBW), abortion and stillbirth, congenital malaria and foetal anaemia. ${ }^{5}$ The risk of IUGR associated with malaria was greatest after three or more cumulative infections (RR 3.3; 95\% CI: 1.3-8.2) and was two to eight-fold higher among women with evidence of undernutrition. ${ }^{6}$ Submicroscopic malaria infections in pregnant women were associated with significantly increased risks of low birth weight in primigravidae and premature births in multigravidae. $^{7}$

According to Poespoprojo ${ }^{8}$ infant malaria is a major public health issue in Timika, Papua (Indonesia) and the risk starts at birth with the majority of malaria cases going undiagnosed, being mostly asymptomatic. Newborns and young infants (less than 6 months of age) are thought to be relatively protected from symptomatic malaria. ${ }^{9}$ This protection has been considered to be primarily mediated by maternal antimalarial IgG antibodies transferred to the foetus in the last trimester of pregnancy. ${ }^{10}$

Antimalarial IgG antibodies may have three roles: first blocking sporozoite invasion of hepatocytes and merozoite invasion of erythrocytes; second, opsonize merozoites and infected erythrocytes expressing variant surface antigens (VSA) on their surface for phagocytosis; and third, fixing and activating complements on the merozoite surface with resultant parasite lysis. ${ }^{11}$ Primarily in the third trimester, transplacental transfer of maternal IgG antibodies to the foetus occurs and is 
mediated by the neonatal Fc receptor. ${ }^{12}$ After birth, all isotypes of maternal antibodies, except for IgA, are transferred to infants in breast milk, despite the fact that these are not systemically absorbed and act primarily in the gut. ${ }^{13}$ The waning of maternal antimalarial $\mathrm{IgG}$ antibodies by 6-9 months of age had been reported previously, which coincides with the period of time in which the risk for malaria infection and clinical disease in infants begins to increase. ${ }^{14}$

Beside transplacental transfer of protective antibodies frommother to foetus, several factors that allegedly contribute to the susceptibility of infants to malaria are innate mechanisms including haemoglobin foetus $(\mathrm{HbF}),{ }^{15}$ para amino benzoic acid (PABA)-deficiency and transforming growth factor (TGF) in breast milk, exclusive breast feeding, ${ }^{16}$ neonatal responses to priming by transplacental transfer of parasites or products, ${ }^{17}$ placental malaria, ${ }^{18}$ infant nutritional status, high exposure to Plasmodium, ${ }^{19}$ and proper implementation of insecticide-treated nets and intermittent preventive treatment. ${ }^{20}$

In placental intervillous spaces the parasite specific adhesion may contribute to placental insufficiency which may relate, either directly or indirectly, to foetal growth restriction and premature birth. Susceptibility of women to placental malaria is attributed to increased parasites sequestered in the placenta mediated by chondroitin sulfate A binding to the trophoblast ${ }^{21}$ and pregnancyassociated suppression of inflammatory responses caused by hormonal changes. ${ }^{22}$ Pregnant women experience immunological and hormonal changes, particularly oestrogen and progesterone which are partly driven by increased levels of pregnancy-associated hormones. ${ }^{23}$ A recent study found the role of soluble human leukocyte antigen G (sHLA-G) in infant susceptibility to malaria during pregnancy. ${ }^{24}$
There were some evidences of the effect of placental malaria on infants, which also includes greater susceptibility to malaria and anaemia in those born to mothers with a parasitized placenta. ${ }^{17,25}$ All these studies have focused on placental infection at delivery, with no exploration of the mother's history of infection earlier during pregnancy. Our study aimed to investigate the impact of MiP on infant susceptibility to malaria infection, taking into account the timing of its occurrence, the number of MiP infections and demographic data during the first year of life.

\section{MATERIALS AND METHODS}

\section{Subjects}

The study was conducted from October 2013 to September 2016 in lowland Timika, Papua Indonesia, an area where P. falciparum and $P$. vivax malaria are similarly prevalent. This was a nested study from a cluster randomized trial of maternal malaria prevention and treatment. Pregnant women with gestational age $<24$ weeks were enrolled at their first antenatal visit at Posyandu (community health centre) after giving written informed consent.

The subjects of this study were the infants born to these mothers who were enrolled consecutively until the number of sample size was sufficient. Inclusion criteria were healthy term newborns and consenting mothers living in the study areas for the duration of followup. The babies would be excluded if preterm (< 37 weeks gestation), sick newborns requiring hospitalization, withdrawal by the parent/mother, and loss to follow-up for more than 6 months.

Sample size of infants was based on the cohort prospective method ${ }^{26}$ with $\mathrm{RR}=2.13$ assumed as significant, where the prevalence of malaria in infants in group without risk factor was $(\mathrm{P} 2)=0.123^{27}$ with $\alpha=0.05$; power 
$80 \% ; z \alpha=1.96$; and $z \beta=0.842$, then the project required a sample size of 162 infants (81 per arm). Ethics approval was obtained from the Medical and Health Research Ethics Committee at the Faculty of Medicine, Universitas Gadjah Mada, Yogyakarta, Indonesia.

\section{Protocol}

Pregnant women were followed-up 3 or 4 times ( 3 if enrolled after 24 weeks and 4 times if enrolled between 16-23 weeks) and again at delivery. At those times blood samples were taken from the finger prick for malaria investigation. Infants born to a mother with either MiP or no MiP would be followed for 1 year and we performed malaria laboratory diagnosis at 6 and 12 months.

The diagnosis of malaria both in mothers and infants were based on PCR examination. Demographic data from the mother included: age, gravidity, ethnicity and bed net utilization while from the baby data included: gender, birth weight, birth length and head circumference. Gestational age at birth were assessed from neuromuscular and physical maturity score of the newborn according to Ballard methods. The procedures were performed by a trained research nurse.

\section{Statistical analysis}

Statistical analysis using SPSS version 22.0 (UGM online license). Numerical data with normal distribution were analyzed using student $t$ test or one way analysis of variance (Anova). If there was an abnormal distribution then it would be analyzed using Mann-Whitney U test. Categorical data were analyzed using chi square test with Yates correction or Fisher exact test. Statistical significance was considered if $\mathrm{p}<0.05$. To control confounding variables and look for independent risk factors from malaria in infants, bivariate and multivariate tests were be performed.

\section{RESULTS}

One hundred and ninety three motherinfant pairs were enrolled between October 2013 and September 2016. There were 4 parental refusals. Among 193 infants, 9 infants did not complete the 12 months follow up (4 infants from mother without MiP and 5 infants from mother with MiP), and 2 infants died from mothers with MiP due to sepsis and watery diarrhoea (FIGURE 1).

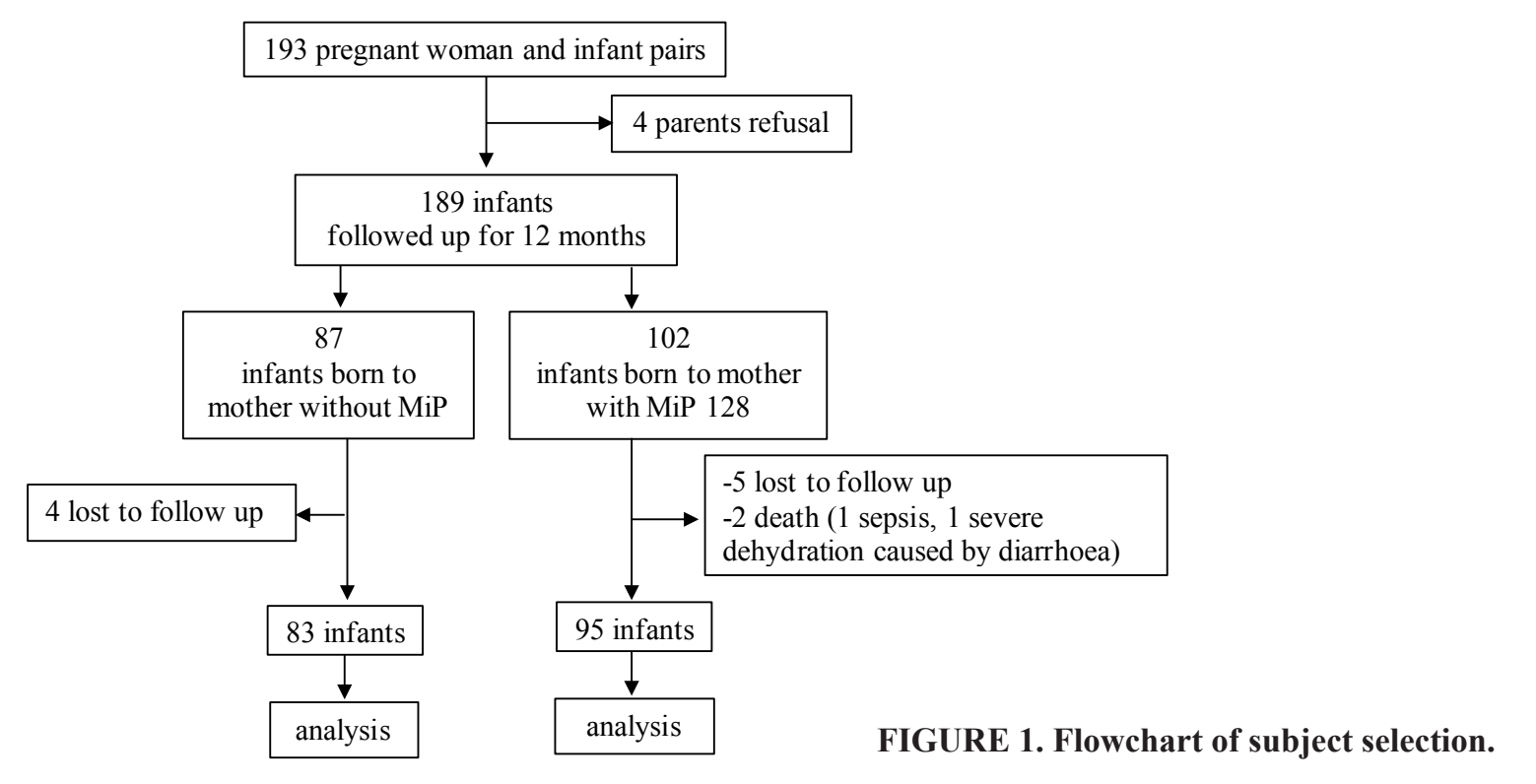


During the pregnancy, 46 women were infected during the $1^{\text {st }}$ trimester, 54 during the $2^{\text {nd }}$ trimester, and 14 during the $3^{\text {rd }}$ trimester. There were 48 (27\%) pregnant women that had at least one malaria infection, 29 (16.3\%) had two infections, $14(7.98 \%)$ had 3 or more infections and 87 (48.9\%) had no infection. During delivery there were 44 mothers who had malaria infection, where 42 mothers had positive placental infection and 22 mothers had peripheral parasitemia. The mean of mother age was $25.35 \pm 6.30$ vs $26.0 \pm 5.69$ years, and the youngest was 12 years old and the oldest was 42 years old (TABLE 1). There were no significant differences in baseline characteristics between mothers with MiP and without MiP.

TABLE 1. Mother baseline characteristics

\begin{tabular}{lccc}
\hline \multicolumn{1}{c}{ Characteristic } & $\begin{array}{c}\text { Malaria in pregnancy }(+) \\
\mathbf{n}=\mathbf{9 5}\end{array}$ & $\begin{array}{c}\text { Malaria in pregnancy (-) } \\
\mathbf{n = 8 3}\end{array}$ & p* \\
\hline Age (years \pm SD) & $25.35 \pm 6.30$ & $26.0 \pm 5.69$ & 0.14 \\
Gravidity, n (\%) & & & \\
- Primigravidae & $31(17.4)$ & $17(9.6)$ & \\
- Secundigravidae & $25(14.0)$ & $34(19.2)$ & 0.69 \\
- Multigravidae & $39(21.9)$ & $32(17.9)$ & \\
Ethnic Group, n (\%) & & & \\
- Papuan & $48(27.0)$ & $38(21.3)$ & 0.53 \\
- Non Papuan & $47(26.4)$ & $45(25.3)$ & \\
Bed net utilization & & & \\
- Yes & $28(15.7)$ & $24(13.5)$ & 0.94 \\
• No & $67(37.6)$ & $59(33.2)$ & \\
\hline
\end{tabular}

*Fisher exact test, significant if $\mathrm{p}<0.05$

TABLE 2 shows that there were 91 (51.12\%) boys and 87 (48.88\%) girls. Birth weight, head circumference and low birth weight were more likely to occur in infants from mothers with MiP positive compared with MiP negative mothers, but these results were not significant $(\mathrm{p}>0.05)$.

TABLE 2. Characteristics of infant

\begin{tabular}{lccc}
\hline \multicolumn{1}{c}{ Characteristics } & $\begin{array}{c}\text { Malaria in Pregnancy (+) } \\
\mathbf{n}=\mathbf{9 5}\end{array}$ & $\begin{array}{c}\text { Malaria in Pregnancy (-) } \\
\mathbf{n}=\mathbf{8 3}\end{array}$ & $\mathbf{p}^{*}$ \\
\hline Gender, $\mathrm{n}(\%)$ & $50(28.1)$ & $41(23.0)$ & \\
• Boy & $45(25.3)$ & $42(23.6)$ & 0.67 \\
• Girl & $3028.95 \pm 450.87$ & $3051.21 \pm 388.13$ & 0.32 \\
Birth weight (mean $\pm \mathrm{SD})$ & $49.13 \pm 2.08$ & $49.02 \pm 2.06$ & 0.68 \\
Birth length (mean $\pm \mathrm{SD})$ & $32.73 \pm 1.56$ & $33.02 \pm 1.62$ & 0.54 \\
Head circumference (mean $\pm \mathrm{SD})$ & $37.76 \pm 1.07$ & $37.53 \pm 0.89$ & 0.45 \\
Gestational age (mean $\pm \mathrm{SD})$ & & & \\
Low birth weight, $\mathrm{n}(\%)$ & $11(6.2)$ & $3(1.7)$ & 0.55 \\
• Yes & $84(47.2)$ & $80(44.9)$ & 0.55 \\
• No & & & \\
\hline
\end{tabular}

*Fisher exact test, significant if $\mathrm{p}<0.05$ 
TABLE 3 shows a bivariate analysis of the effects of MiP on infant malaria infections at age 6 and 12 months in which infants born to mother with $\mathrm{MiP}$ were more susceptible to malaria infection than infants born to mother without $\operatorname{MiP}(\mathrm{p}=0.03 ; \mathrm{RR}=3.49 ; 95 \% \mathrm{CI}$ $1.02-11.96)$ and $(\mathrm{p}=0.01 ; \mathrm{RR}=8.74 ; 95 \% \mathrm{CI}$ 1.14-66.81) respectively.

TABLE 3. Malaria infant in 6 and 12 months old

\begin{tabular}{clccccc}
\hline \multirow{2}{*}{ Variable } & & \multicolumn{2}{c}{ Malaria Infant, $\mathbf{n}(\mathbf{\%})$} & p* & RR & 95\% CI \\
\hline \multirow{2}{*}{6 months old } & MiP $(+)$ & $12(12.63)$ & $83(87.37)$ & 0.03 & 3.49 & $1.02-11.96$ \\
& MiP (-) & $3(3.61)$ & $80(96.39)$ & & & \\
\multirow{2}{*}{12 months old } & MiP (+) & $10(10.53)$ & $85(89.47)$ & 0.01 & 8.74 & $1.14-66.81$ \\
& MiP (-) & $1(1.21)$ & $82(98.79)$ & & \\
\hline
\end{tabular}

*Fisher exact test, significant if $\mathrm{p}<0.05$

We performed a multivariate analysis between all malaria infections over a period of 12 months with malaria-infected timings and maternal demographics (TABLE 4). In this study we found that MiP which occurred in second trimester, pregnant women who only had malaria infection 1 time before delivery and Papuan ethnicity were independent factors related to the infant susceptibility to malaria infection.

TABLE 4. Factors related to susceptibility infant to malaria infection at 6 and 12 months old

\begin{tabular}{|c|c|c|c|c|c|c|c|c|}
\hline \multirow{2}{*}{ Characteristics } & \multicolumn{2}{|c|}{ Infant Parasitemia } & \multicolumn{3}{|c|}{ Crude } & \multicolumn{3}{|c|}{ Logistic Regression } \\
\hline & $(+)$ & $(-)$ & $\mathbf{R R}$ & $95 \% \mathrm{CI}$ & $\mathbf{p}$ & $\mathbf{R R}$ & $95 \% \mathrm{CI}$ & $\mathbf{p}$ \\
\hline \multicolumn{9}{|c|}{ Malaria during pregnancy } \\
\hline \multicolumn{9}{|l|}{${ }^{1 s t}$ Trimester } \\
\hline - Yes & $2(20.0)$ & $8(80.0)$ & \multirow{2}{*}{1.77} & \multirow{2}{*}{$0.48-6.55$} & \multirow{2}{*}{0.41} & \multirow{2}{*}{2.76} & \multirow{2}{*}{$0.41-18.43$} & \multirow{2}{*}{0.29} \\
\hline • No & $19(11.3)$ & $149(88.7)$ & & & & & & \\
\hline \multicolumn{9}{|l|}{${ }^{2 n d}$ Trimester } \\
\hline - Yes & $12(25.0)$ & $36(75.0)$ & \multirow{2}{*}{3.61} & \multirow{2}{*}{ 1.63-8.02 } & \multirow{2}{*}{0.00} & \multirow{2}{*}{4.21} & \multirow{2}{*}{ 1.36-13.60 } & \multirow{2}{*}{0.01} \\
\hline • No & $9(6.9)$ & $121(93.1)$ & & & & & & \\
\hline \multicolumn{9}{|l|}{ 3rdTrimester } \\
\hline - Yes & $5(13.5)$ & $32(86.5)$ & \multirow{2}{*}{1.19} & \multirow{2}{*}{$0.47-3.04$} & \multirow{2}{*}{0.72} & \multirow{2}{*}{0.99} & \multirow{2}{*}{$0.27-3.74$} & \multirow{2}{*}{0.99} \\
\hline - No & $16(11.3)$ & $125(88.7)$ & & & & & & \\
\hline \multicolumn{9}{|l|}{ Malaria infection 1 time } \\
\hline - Yes & $9(18.8)$ & $39(81.2)$ & \multirow{2}{*}{2.03} & \multirow{2}{*}{$0.91-4.51$} & \multirow{2}{*}{0.81} & \multirow{2}{*}{3.39} & \multirow{2}{*}{$1.09-10.57$} & \multirow{2}{*}{0.03} \\
\hline - No & $12(9.2)$ & $118(90.8)$ & & & & & & \\
\hline \multicolumn{9}{|l|}{ Parasitemia at Delivery } \\
\hline Peripheral & & & & & & & & \\
\hline - Yes & $4(16.7)$ & $20(83.3)$ & & & & & & \\
\hline • No & $17(11.0)$ & $137(89.0)$ & 1.51 & $0.56-4.11$ & 0.43 & 2.43 & $0.18-33.64$ & 0.51 \\
\hline Placental & & & & & & & & \\
\hline - Yes & $6(14.6)$ & $35(85.4)$ & & & & & & \\
\hline - No & $15(10.9)$ & $122(89.1)$ & 1.34 & $0.55-3.22$ & 0.51 & 2.99 & $0.41-22.12$ & 0.28 \\
\hline
\end{tabular}




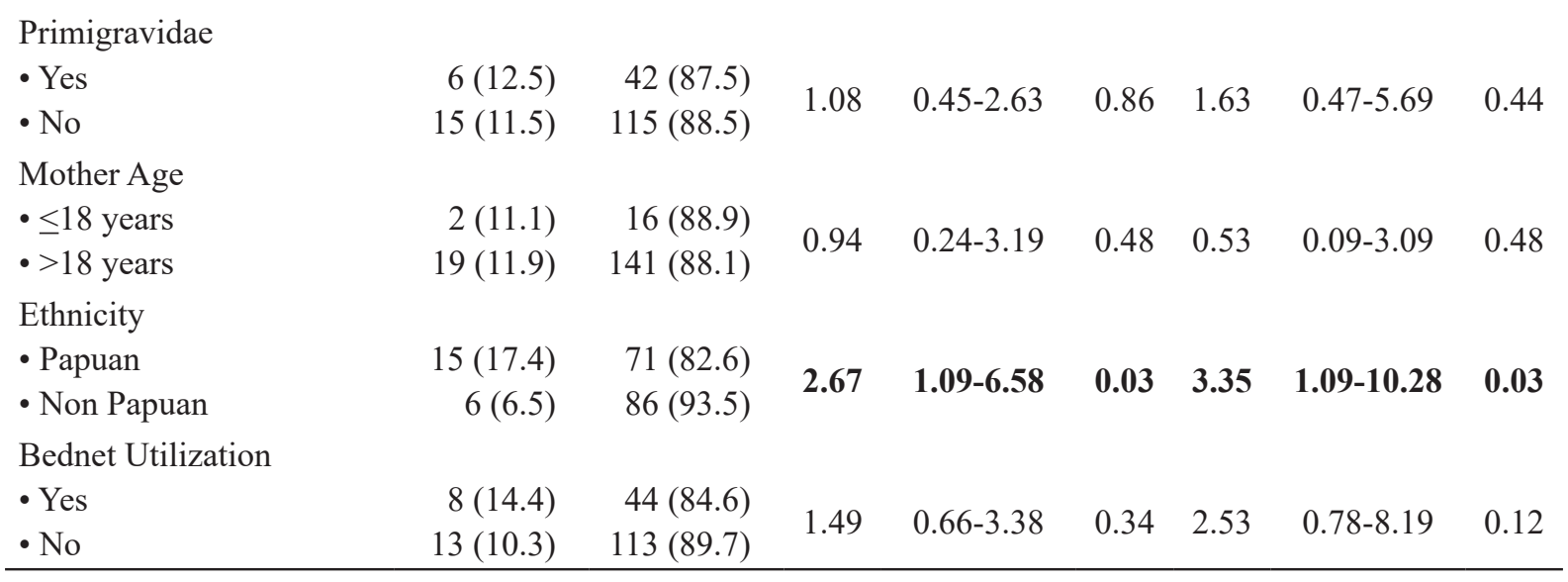

\section{DISCUSSION}

We found that at 6 and 12 months old, MiP was related to malaria infection in infants. This study is consistent with previous studies that found a significant relationship between MiP and infant susceptibility to malaria infection ${ }^{27}$ and it also correlated with the increasing of malaria episodes during infancy. ${ }^{28}$ Infants born to positive MiP mothers are more susceptible to malaria, presumably because placental malaria causes the transfer of maternal antibody decrease ${ }^{29}$ leading to increase of infant susceptibility to malaria infection.

Our study found that after logistic regression analysis, MiP occurrence in the second trimester was independently associated with infant susceptibility to malaria infection in the first year of life $(\mathrm{RR}=4.21 ; 95 \% \mathrm{CI} 1.36$ 13.60; $p=0.01$ ) (TABLE 4). This finding is in contrast with the result of a previous study ${ }^{18}$ that found MiP in the third trimester increased the risk of malaria infection during the first year of life. The association between MiP in the second trimester and infant susceptibility to malaria infection was thought to be related to the duration of malaria exposures in the mother. ${ }^{22}$ Malhotra et al. ${ }^{17}$ reported a tolerant immune process that occurred depending on the type of malaria antigen in contact with the foetus, the number of parasites and the duration of exposure and timing during pregnancy. This finding supports the premise that although the mother was exposed to malaria but the foetus has not been sensitized, so the infants are more susceptible to malaria infection. ${ }^{17}$ Boudova et al. ${ }^{18}$ reported that only placental infection during pregnancy is associated with increased risk of malaria in infancy, but in this study we found there was no significant correlation between placental malaria and infant susceptibility to malaria.

Another study reported that primigravidae are at greater risk of $\mathrm{MiP}$ compared to multigravidae $^{30}$ and their offspring are also more susceptible to malaria infection mainly as a result of reduced antibody transfer. ${ }^{31}$ Yet in this study we did not find support for this conclusion. However, this study found that pregnant women who suffered from malaria as much as 1 time before delivery were associated with infant susceptibility to malaria infection. Among 26 cases of malaria in infants at 6 and 12 months of age, there were 4 infants who had malaria twice. The remaining of 21 cases consisted of 5 infants born to mothers without MiP, 7 infants born to mothers with MiP who had a different plasmodium species as their mothers and 9 infants born to mothers with MiP had the same plasmodium species as their mothers. 
In all of the 9 infants who have the same species as their mothers, malaria infection of the mother occurred 1 time during the second trimester. This phenomenon corresponds to the theory that naturally acquired immunity develops over time after repeated infections ${ }^{10}$ and the development of antimalarial antibodies as well as maternal antimalarial antibodies transferred to the foetus in the last trimester are thought to play a crucial role. ${ }^{28}$ In malaria endemic areas like in Timika Papua, individuals develop naturally acquired immunity to both $P$. falciparum and $P$. vivax after repeated infections. ${ }^{2}$ This immunity does not generally protect against infection per se, but protects against the development of high parasite densities and clinical symptoms. ${ }^{32}$ HLA-G might play an important role in infant susceptibility to infection. A high level of soluble HLA-G (sHLA-G), a non-classical HLA class Ib antigen, with important immuneregulatory functions ${ }^{33}$ was significantly associated with a higher incidence ratio of malaria in children. ${ }^{34}$ It was consistent with the fact that the inhibition of immune responses by HLA-G expression could lead to a greater susceptibility to malaria. ${ }^{24}$ In this study infant susceptibility to malaria infection besides being associated to MiP was also significantly correlated to Papuan ethnic $(\mathrm{RR}=3.35 ; 95 \% \mathrm{CI}$ 1.09-10.28; $\mathrm{p}=0.03$ ) (TABLE 4). This finding is consistent with previous research that found an association between Papuan ethnicity and the risk of parasitemia in pregnant women. ${ }^{8}$

Although a complete explanation of the pathophysiology of MiP has not yet been developed, exposure to malaria intrauterine probably correlates with placental sequestration of erythrocytes. The immune tolerance process then depends on the type of malaria antigen in contact with the foetus, the amount and the duration of the exposure, and the timing of exposure during pregnancy. The timing of malaria episodes during pregnancy results in different effects on both the mother and the foetus, where parasitaemia appears to be higher during the first and second trimesters, although followup on $P$. falciparum parasitaemia during the first trimester has seldom been complete. ${ }^{35}$

\section{CONCLUSIONS}

Infant susceptibility to malaria is associated with maternal malaria status during pregnancy. MiP in the second trimester, pregnant women who only had malaria once and Papuan ethnicity are independent risk factors for infant's increased susceptibility to malaria infection.

\section{ACKNOWLEDGMENTS}

We are grateful to Amungme and Kamoro Commuity Development Foundation, Mimika, Papua. We would also like to thank the study participants for their significant contribution to the study, the research assistants, field and laboratory staff of the Papua Health and Community Development Foundation. This study was supported by The National Institute of Health Research and Development-Menzies School and Wellcome Trust National Health and Medical Research Council (NHMRC).

\section{REFFERENCES}

1. World Health Organization. World malaria report. [serial online] 2014. [cited January 20th, 2017]. Available from: http://www. who.int/malari/publications/world-malariareport-2014/report/en/

2. McLean AR, Ataide R, Simpson JA, Beeson JG, Fowkes FJ. Malaria and immunity during pregnancy and postpartum: a tale of two species. Parasitology 2015; 142(8):999-15. https://doi.org/10.1017/S0031182015000074 
3. Dellicour S, Tatem AJ, Guerra CA, Snow RW, ter Kuile FO. Quantifying the number of pregnancies at risk of malaria in 2007: a demographic study. PLoS Med 2010; 7:e1000221.

https://doi.org/10.1371/journal. pmed.1000221

4. Moya-Alvarez V, Abellana R, Cot M. Pregnancy-associated malaria and malaria in infants: an old problem with present consequences. Malar J 2014; 13(1): 271. http://dx.doi.org/10.1186/1475-2875-13-271. https://doi.org/10.1186/1475-2875-13-271

5. World Health Organization. World malaria report. [serial online] 2012. [cited January 20th, 2017]. Available from: http://www. who.int/malari/publications/world-malariareport-2012/report/en/

6. Landis $\mathrm{SH}$, Lokomba V, Ananth CV, Atibu J, Ryder RW, Hartmann KE, et al. Impact of maternal malaria and under-nutrition on intrauterine growth restriction: a prospective ultrasound study in Democratic Republic of Congo. Epidemiol Infect 2009; 137(2): 294304.

https://doi.org/10.1017/S0950268808000915

7. Cottrell G, Moussiliou A, Luty AJ, Cot $\mathrm{M}$, Fievet N, Massougbodji A, et al. Submicroscopic Plasmodium falciparum infections are associated with maternal anemia, premature births, and low birth weight. Clin Infect Dis 2015; 60(10):1481-8. https://doi.org/10.1093/cid/civ122

8. Poespoprodjo JR, Fobia W, Kenangalem E, Lampah DA, Warikar N, Seal A, et al. Adverse pregnancy outcomes in an area where multidrug-resistant Plasmodium vivax and Plasmodium falciparum infections are endemic. Clin Infect Dis 2008; 46(9):1374-81. https://doi.org/10.1086/586743

9. Apinjoh TO, Anchang-Kimbi JK, Mugri RN, Njua-Yafi C, Tata RB, Chi HF, et al. Determinants of infant susceptibility to malaria during the first year of life in South Western Cameroon. Open Forum Infect Dis 2015; 2(1): ofv012. http://dx.doi.org/ 10.1093/ofid/ofv012. eCollection 2015 Jan. https://doi.org/10.1093/ofid/ofv012

10. Dobbs KR, Dent AE. Plasmodium malaria and antimalarial antibodies in the first year of life. Parasitology. 2016;143(2):129-38. https://doi.org/10.1017/S0031182015001626

11. Hill DL, Eriksson EM, Suen CS, Chiu CY, Ryg-Cornejo V, Robinson LJ, et al. Opsonising antibodies to $\mathrm{P}$. falciparum merozoites associated with immunity to clinical malaria. PLoS One 2013; 8(9):e74627. https://doi.org/10.1371/journal.pone.0074627

12. Simister NE. Placental transport of immunoglobulin G. Vaccine 2003; 21(24): 3365-9.

https://doi.org/10.1016/S0264410X(03)00334-7

13. Van de Perre P. Transfer of antibody via mother's milk. Vaccine 2003; 21(24): 3374-6. https://doi.org/10.1016/S 0264 410X(03)00336-0

14. Nhabomba AJ, Guinovart C, Jimenez A, Manaca MN, Quinto L, Cistero $P$, et al. Impact of age of first exposure to Plasmodium falciparum on antibody responses to malaria in children: a randomized, con- trolled trial in Mozambique. Malar J 2014; 13: 121. http:// dx.doi.org /13:121. doi: 10.1186/1475-287513-121.

https://doi.org/10.1186/1475-2875-13-121

15. Amaratunga C, Lopera-Mesa TM, Brittain NJ, Cholera R, Arie T, Fujioka H, et al. A role for fetal hemoglobin and maternal immune IgG in infant resistance to Plasmodium falciparum malaria. PloS one. 2011; 6(4): e14798. https://doi.org/10.1371/journal.pone.0014798

16. Brazeau NF, Tabala M, Kiketa L, Kayembe D, Chalachala JL, Kawende B, et al. Exclusive breastfeeding and clinical malaria risk in 6-month-old infants: a cross-sectional study 
from Kinshasa, Democratic Republic of the Congo. AJTMH 2016; 95(4): 827-30. https://doi.org/10.4269/ajtmh.16-0011

17. Malhotra I, Dent A, Mungai P, Wamachi A, Ouma JH, Narum DL, et al. Can prenatal malaria exposure produce an immune tolerant phenotype? A prospective birth cohort study in Kenya. PLoS Med 2009; 6:e1000116.

https://doi.org/10.1371/journal. pmed.1000116

18. Boudová S, Divala T, Mungwira R, Mawindo P, Tomoka T, Laufer MK. Placental but not peripheral Plasmodium falciparum infection during pregnancy is associated with increased risk of malaria in infancy. J Infect Dis 2017; 216:732-5

https://doi.org/10.1093/infdis/jix372

19. Hviid L, Staalsoe T. Malaria immunity in infants: a special case of a general phenomenon?. Trends Parasitol 2004; 20(2):66-72.

https://doi.org/10.1016/j.pt.2003.11.009

20. Hartman TK, Rogerson SJ, Fischer PR. The impact of maternal malaria on newborns. Ann Trop Paediatr 2010; 30(4):271-82 https://doi.org/10.1179/14653281 0X12858955921032

21. Muthusamy A, Achur RN, Valiyaveettil M, Botti JJ, Taylor DW, Leke RF, et al. Chondroitin sulfate proteoglycan but not hyaluronic acid is the receptor for the adherence of Plasmodium falciparum-infected erythrocytes in human placenta, and infected red blood cell adherence up-regulates the receptor expression. Am J Pathol 2007; 170: 1989-2000 https://doi.org/10.2353/ajpath.2007.061238

22. Menzies FM, Henriquez FL. Immunomodulation by the female sex hormones. Open Infect Dis J 2009; 3: 61-72.

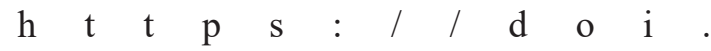
org/10.2174/1874279300903010061

23. Dione PR, Klein SL. Pregnancy and pregnancy-associated hormones alter immune responses and disease pathogenesis. Horm Behav 2012; 62 (3): 263-71. https://doi.org/10.1016/j.yhbeh.2012.02.023

24. d'Almeida TC, Sadissou I, Cottrell G, Tahar R, Moreau P, Favier B, et al. Evolution of the levels of human leukocyte antigen $G$ (HLA-G) in Beninese infant during the first year of life in a malaria endemic area: using latent class analysis. Malar J 2016; 15(1):78. https://doi.org/10.1186/s12936-016-1131-y

25. Bardají A, Bassat Q, Alonso PL, Menéndez C. Intermittent preventive treatment of malaria in pregnant women and infants: making best use of the available evidence. Expert Opin Pharmacother 2012;13(12):1719-36. https://doi.org/10.1517/14656566.2012.703651

26. Sastroasmoro S \& Ismail S. Dasar-dasar metodologi penelitian klinis. 5th ed. Jakarta: Sagung Seto 2014.

27. Mutabingwa TK, Bolla MC, Li JL, Domingo GJ, Li X, Fried M, et 1. Maternal malaria and gravidity interact to modify infant susceptibility to malaria. PLoS Med 2005; 2(12): e407.M Borgella S, Fievet N, Huynh B-T, Ibitokou S, Hounguevou G, Affedjou J, et al.Impact of pregnancy-associated malaria on infant malaria infection in southern Benin. PLoS One. 2013; 8:e80624 https://doi.org/10.1371/journal.pone.0080624

28. Rogerson SJ, Hviid L, Duff PE, Leke RFG, Taylor DW. Malaria in pregnancy: pathogenesis and immunity. Lancet Infect Dis 2007; 7:105-17.

https://doi.org/10.1016/S14733099(07)70022-1

29. Okoko BJ, Wesumperuma LH, Ota MO, Pinder M, Banya W, Gomez SF, et al. The influence of placental malaria infection and maternal hypergammaglobulinemia on transplacental transfer of antibodies and IgG subclasses in a rural West African population. $\mathrm{J}$ Infect Dis 2001; 184:627-32. https://doi.org/10.1086/322808 
30. Borgella S, Fievet N, Huynh B-T, Ibitokou $\mathrm{S}$, Hounguevou G, Affedjou J, et al.Impact of pregnancy-associated malaria on infant malaria infection in southern Benin. PLoS One. 2013; 8:e80624

https://doi.org/10.1371/journal.pone.0080624

31. Desai M, Kuile FO, Nosten F, Mcgready R, Asamoa K, Brabin B, et al. Epidemiology and burden of malaria in pregnancy. Lancet Infect Dis. 2007; 7(2): 93-104. https://doi.org/10.1016/S14733099(07)70021-X

32. Langhorne J, Ndungu FM, Sponaas AM, Marsh K. Immunity to malaria: more questions than answers. Nat Immunol 2008; 9(7):725-32.

https://doi.org/10.1038/ni.f.205

33. Larsen MH, Bzorek M, Pass MB, Larsen LG, Nielsen MW, Svendsen SG, et al. Human leukocyte antigen-G in the male reproductive system and in seminal plasma. Mol Hum Reprod 2011; 17:727-38.

https://doi.org/10.1093/molehr/gar052

34. Sadissou I, d'Almeida T, Cottrell G, Luty A, Krawice-Radanne I, Mas- sougbodji A, et al. High plasma levels of HLA-G are associated with low birth weight and with an increased risk of malaria in infancy. Malar J 2014; 13: 312. http://dx.doi.org / doi:10.1186/1475-2875-13-312.

35. Kalilani-Phiri L, Thesing PC, Nyirenda OM, Mawindo P, Madanitsa M, Membe $\mathrm{G}$, et al. Timing of malaria infection during pregnancy has characteristic maternal, infant and placental outcomes. PLoS One 2013; 8:e74643.

https://doi.org/10.1371/journal.pone.0074643 